\title{
"Balinese Language Masatwa" Learning: A Strategy of Balinese Language Learning and Character Education for the Balinese Young Generation
}

\author{
I Nyoman Kardana, A.A. Istri Manik Warmadewi, I Gusti Ayu Agung Dian Susanthi \\ \{ikardana@yahoo.com\} \\ Warmadewa University
}

\begin{abstract}
Bali tourism development as well as the advances in information and technology has significantly influenced the lifestyles and mindsets of the Balinese people. For example, the people are more happy and proud to master and use foreign languages than Balinese in their daily lives because they believe these languages open more opportunities for them to compete in the world of work in the tourism sector. Therefore, these changes in behavior need adequate attention from various parties, especially the education sector. Balinese language as a medium of community communication in relation to traditional activities, religion and culture needs to be maintained to avoid going extinct. This is because the language is not only a communication tool rather it also contains messages and moral values related to local wisdom. According to several studies, the inability of some Balinese younger generation to understand and use the language is one of the factors leading to the decline in their morale and behavior. Therefore, to produce future reliable generations with good behavior (soft skills), the education system in Bali need to emphasize on the academic ability of students, provide good behavioral knowledge (soft skills) and motivates them to like and understand the language. Therefore, mastery of the local Balinese language and character education need to be continuously improved to produce highly competitive young generation in the current globalization era. Gulo (1987) defined character as a personality viewed from an ethical or moral starting point, such as someone's honesty, which is usually associated with relatively fixed traits. One of the possible efforts in character education is "Balinese Language Masatwa" learning system which tends to motivate students to enjoy and understand the language as well as the characters and moral values contained in each story line. Balinese stories also known as satwa contain many values related to community's local wisdom.
\end{abstract}

Keywords: Balinese language, moral values, character education, local wisdom.
Abstrak. Perkembangan pariwisata Bali telah membawa dampak yang besar terhadap perilaku masyarakat Bali. Wisatawan domestik dan asing yang berkunjung dan tinggal menetap di Bali telah mempengaruhi warna kehidupan masyarakat Bali. Di samping itu, kemajuan teknologi informasi juga memberikan pengaruh yang besar terhadap pola hidup dan pola pikir 
masyarakat Bali. Misalnya, penghargaan masyarakat Bali terhadap bahasa Bali sebagai salah satu unsur budaya Bali semakin lama semakin menurun. Masyarakat lebih senang dan bangga untuk bisa menguasai dan menggunakan bahasa asing dari pada bahasa Bali dalam kehidupan sehari-hari. Alasannya, bahwa menguasai bahasa asing jauh lebih menjanjikan dari pada bahasa Bali. Menguasai bahasa asing lebih membuka peluang untuk mampu bersaing dalam dunia pekerjaan di sektor pariwisata. Kenyataan yang telah mengubah perilaku masyarakat Bali tersebut perlu mendapat perhatian berbagai pihak, khususnya dunia pendidikan. Bahasa Bali sebagai media komunikasi masyarakat Bali dalam kaitannya dengan aktifitas adat, agama, dan budaya Bali harus dijaga kedudukan dan fungsinya. Sesungguhnya, bahasa Bali tidak saja sebagai alat komunikasi, tetapi dalam bahasa Bali juga terbungkus pesan dan nilai-nilai moral yang berhubungan dengan kearifan lokal (local genius) masyarakat Bali. Dengan demikian, ketidakmampuan sebagaian generasi muda Bali memahami dan menggunakan bahasa Bali telah menjadi salah satu faktor penyebab terjadinya kemerosotan moral dan perilaku generasi muda Bali. Sehubungan dengan itu, untuk menghasilkan generasi penerus yang handal dan memiliki perilaku (soft skill) yang baik, pendidikan di Bali tidk hanya menekankan pada kemampuan akademik siswa tetapi juga memberikan pengetahuan perilaku (soft skill) yang baik kepada siswa sebagai generasi muda Bali dan memotivasi generasi muda untuk menyukai dan memahami bahasa Bali. Jadi, penguasaan bahasa Bali (sebagai bahasa lokal) dan pendidikan karakter sangat perlu ditingkatkan secara berkelanjutan untuk menghasilkan generasi muda yang berdaya saing tinggi dalam era globalisasi dewasa ini. Karakter itu sendiri merupakan suatu kepribadian yang ditinjau dari titik tolak etis atau moral, seperti kejujuran seseorang, yang biasanya mempunyai kaitan dengan sifat-sifat relative tetap (Gulo, 1987).. Salah satu upaya yang memungkinkan dilakukan dalam kaitannya dengan pendidikan karakter adalah pembelajaran "Masatwa Bahasa Bali". Dengan sistem pembelajaran ini siswa akan termotivasi untuk menyenangi dan memahami bahasa Bali dan siswa juga mengetahui nilai-nilai moral yang terkandung dalam setiap alur cerita dan karakter dari masing-masing tokoh yang ada dalam cerita tersebut. Cerita /satwa bahasa Bali banyak mengandung nilai-nilai yang berhubungan dengan kearifan lokal Bali.

Kata Kunci: Bahasa Bali, nilai moral, pendidikan karakter, kearifan lokal.

\section{Pendahuluan}

Bali sebagai daerah pariwisata dunia telah memikat setiap orang untuk datang dan berkunjung ke Bali. Perkembangan pariwisata Bali yang disertai dengan perkembangan teknologi informasi yang sangat pesat dewasa ini telah memberikan dampak positif dan negatif terhadap masyarakat Bali. Untuk memajukan sektor pariwisata sangat dibutuhkan tenaga professional di bidang pariwisata yang mampu menguasai dan menggunakan bahasa Inggris dengan baik. Perkembangan pariwisata Bali telah menyebabkan terjadinya pergeseran dan perubahan mindset masyarakat Bali, khususnya generasi muda Bali. Memiliki kemampuan bahasa Inggris yang baik memudahkan mereka memperoleh pekerjaan dan dapat meningkatkan daya saing untuk kesejahteraan kehidupana mereka. Hal itu menyebabkan 
perhatian masyarakat Bali lebih mengedepankan penguasaan dan pemakain bahasa asing dan juga bahasa nasional (bahasa Indonesaia) dari pada bahasa Bali sebagai satu-satunya bahasa daerah di Bali. Menguasai bahasa asing, khususnya bahasa Inggris juga dipikir dapat meningkatkankan prestise dan membuka peluang besar untuk memenagkan persaingan global. Namun, di sisi lain hal itu telah menyebabkan menurunnya minat generasi muda Bali untuk memahami dan mnggunakan bahasa Bali dengan baik dalam kehidupan sehari-hari. Sesungguhnya, di sisi lain bahasa Bali sebagai bagian dari budaya Bali seharusnya tetap dijaga dan dihargai sebagai kekayaan dan kebanggaan masyarakat Bali. Bahasa Bali dapat menjadi kekuatan besar dalam memperkuat dan meningkatkan perilaku dan karakter masyarakat Bali, khususnya bagi generasi muda Bali.

Bahasa merupakan suatu hal yang mempunyai latar belakang dengan kapasitas neurobiologis dan psikologis pada manusia yang mendukung kompetensi kita sebagai makhluk yang menggunakan bahasa (Searle, 1990). Generasi muda Bali yang cenderung mengabaikan pentingnya bahasa Bali dalam kehidupana berbudaya di Bali adalah anak-anak dan remaja yang hidup di daerah perkotaan seperti Denpasar. Menurunnya minat generasi muda dalam memahami dan menggunakan bahasa Bali menjadi salah satu penyebab terjadinya kemerosotan moral dan etika perilaku generasi muda Bali. Hal itu didasari oleh pemikiran bahwa bahasa Bali sesungguhnya bukan hanya sebagai alat komunikasi masyarakat Bali, tetapi bahasa Bali juga mengandung nilai-nilai moral dan etika yang berhubungan dengan karakter masyarakat Bali yang telah ada sejak zaman dahulu. Ini sejalan dengan pendapat Mbete (2014) yang menyatakan bahwa bahasa berfungsi sebagai representasi realitas kehidupan yang ada dalam lingkungan, baik lingkungan sosial-budaya sebagai jagat kecil (mikrokosmos) maupun lingkungan alam sebagai jagat agung (makrokosmos). Fenomena yang terjadi adalah kurangnya masyarakat Bali khususnya generasi muda di kota Denpasar menggunakan bahasa Bali dalam berkomunikasi, namun kebanyakan orang lebih cenderung mengikuti gaya hidup orang asing/ wisatawan asing yang dating ke Bali sebagai akibat dari aktivitas pariwisata di Kota Denpasar. Selain itu masyarakat kota Denpasar lebih sering berinteraksi dalam berkomunikasi dengan menggunakan bahasa Indonesia (Suarjana, 2008, p. 8). Terjadinya degradasi moral pada generasi muda Bali yang berhubungan dengan nilai karakter masyarakat Bali dapat membahayakan masyarakat Bali itu sendiri. Hal itu kini menjadi masalah besar yang segera harus dicarikan solusinya mengingat arus globalisasi yang terjadi saat ini dan nanti sangat memerlukan generasi muda yang kuat dan tangguh untuk menyaring dan mengantisipasi hal-hal yang tidak diinginkan masuk ke dalam kehidupan masyarakat Bali. Di samping itu, generasi muda harus mempersiapkan dirinya dengan baik, baik moral maupun fisik yang berhubungan dengan pengetahuan dan pengalaman untuk memenangkan persaingan global yang terjadi. Jadi, pengetahuan merupakan suatu yang sangat penting ditingkatkan pada generasi muda untuk menjaga dan melestarikan budaya daerah dan bangsa. Pengetahuan merupakan sesuatu yang kita buat sendiri sebagai hasil konstruksi kognitif melalui kegiatan individu dengan membuat struktur, kategori, konsep, dan skema yang diperlukan untuk dapat membangun pengetahuan tersebut (Cahyo, 2013). Salah satu solusi yang ditawarkan dalam usulan ini adalah Pembelajaran Masatua Bahasa Bali kepada Siswa Sekolah Dasar. Dipilihnya siswa sekolah dasar karena pada usia di bawah 12 tahun pada umumnya mereka masih belum banyak terkontraminasi oleh sentuhan arus globalisasi dan teknologi informasi dan mereka cenderung akan bisa mengikuti dan menyimak nilai-nilai yang disampaikan dalam setiap pembelajaran Masatwa Bahasa Bali tersebut. Sehubungan dengan rasionale di atas, kegiatan ini akan dilaksanakan di kota Denpasar dengan pertimbangan siswa sekolah dasar yang ada di Denpasar dalam kehidupan sehari-hari cenderung menggunakan bahasa Indonesia dalam berbagai tujuan komunkasi. 
Sebagaian besar dari mereka juga memiliki niat yang tinggi untuk menguasai bahasa asing, khususnya bahasa Inggris. Hal itu cenderung akan semakin meninggalkan pemakaian bahasa Bali dalam kehidupan sehari harinya.

Salah satu komunitas yang dapat mewakili generasi muda Bali yang hidup di perkotaan adalah SDN 8 Dauh Puri Denpasar. Sekolah tersebut menjadi salah satu Sekolah Binaaan Dinas Pendidikan Kota Denpasar dan sekolah tersebut sangat terkenal dan menjadi sekolah negeri favorite di kalangan generasi muda di Denpasar. Dari pengamatan sementara diketahui bahwa siswa sekolah tersebut berasal dari keluarga golongan ekonomi menengah ke atas dan orang tua mereka kebanyakan bukan penduduk asli Denpasar. Mereka kebanyakan dari daerah lain di Bali yang bekerja dan menetap di Denpasar dalam kurun waktu yang cukup lama. Siswa sekolah tersebut dalam kehidupan sehari-harinya cenderung menggunakan bahasa Indonesia dari pada bahasa Bali baik di lingkungan keluarga maupun lingkungan sekolah. Banyak juga dari mereka yang sudah menguasai bahasa Inggris dengan baik mengingat orang tuanya sangat mendukung dan memberikan kesempatan bagi mereka untuk meningkatkan bahasa Inggris melalui kursus-kursu bahasa Inggris atau kursus lainnya yang menggunakn bahasa Inggris sebagai media. Dari alasan tersebut, SD N 8 Dauh Puri Denpasar dipilih sebagai kelompok mitra dari kegiatan pengabdian ini. Sekolah tersebut sangat tepat dijadikan sampel dari generasi muda Bali yang sedang menghadapi gradasi moral akibat kurang paham dan mapunya menggunakan bahasa Bali sebagai media komunikasi dalam kehidupan seharihari di lingkungan perkotaan. Adapun kelas yang dipilih adalah kelas IV A dengan jumlah siswa 44 orang, dan kelas IV B dengan jumlah siswa sebanyak 45 orang siswa.

\section{Metode Penelitian}

Permasalahan yang dihadapi oleh generasi muda Bali, yang tergolong dalam kelompok mitra yang dijelaskan di atas telah menginspirasi tim pengusul untuk mengusulkan sebuah solusi yang dapat dilakukan untuk meningkatkan dan memperkokoh karakter generasi muda Bali. Solusi yang ditawarkan adalah Pembelajaran Masatwa Bahasa Bali kepada Siswa Kelas IV SDN 8 Dauh Puri Denpasar. Dengan sistem pembelajaran para siswa (sebagai generasi muda) akan memahami nilai-nilai yang terkandung dalam cerita/satwa dan diharapkan nilainilai tersebut dapat diamalkan dalam kehidupan sehari-harinya. Dengan cara bercerita yang baik, maka anak-anak yang mendengarkan cerita akan menggunakan imajinasi mereka dalam memahami cerita. Mereka dapat menggambarkan isi cerita dari deskriptif pembaca cerita. Hal ini juga bergantung pada bagaimana pembaca cerita dapat menghidupkan ceritanya dan bagaimana pendengar aktif menginterprestasikan apa yang didengarnya (Subyantoro, 2013). Hal itu akan mampu membantu generasi muda dalam menentukan jati dirinya sebagai bagian dari masyarakat Bali dan mampu menunjukkan karakter yang unggul dan memenangkan persaingan global yang terjadi dewasa ini. Langkah-langkah yang diterapkan dalam pelaksanaan Pembelajaran Masatwa Bahasa Bali adalah sebagai berikut. Pertama dilakukan seleksi terhadap cerita/satwa berbahasa Bali yang sesuai dengan siswa sekolah dasar. Siswa yang menjadi objek kegiatan adalah siswa kelas IV. Selanjutnya dilakukan FGD antara tim pelaksana dengan kelompok mitra untuk membicarakan metode yang dilaksanakan dalam pembelajaran tersebut sehingga pembelajaran dapat berlangsuing dengan sukses sesuai rencana. Metode bercerita, yang dalam bahasa Bali disebut dengan Mesatua sangat tepat diterapkan mengingat bercerita merupakan seni atau teknik budaya kuno untuk menyampaikan suatu peristiwa yang dianggap penting, melalui kata-kata, imaji dan suara-suara 
(Ismoerdijahwati, 2007). Setelah semua rencana disetujui, masing-masing pihak melakukan tugas dan tanggung jawabnya. Langkah selanjutnya adalah pelaksanaan pre-test untuk mengetahui pemahaman siswa terhadap nilai-nilai moral masyarakat Bali. Langkah berikutnya dilakukan pembelajaran masatwa selama 6 minggu untuk masing-masing kelas, yaitu sebanyak 1 kali pertemuan/minggu dengan durasi waktu 90 menit/pertemuan. Setelah selesai pembelajaran dilakukan post-test untuk mengetahui kemajuan pemahaman terhadap nilai-nilai moral yang terdapat dalam masyarakaty Bali yang tertuang dalam setiap cerita (baik alur, tema, maupun tokoh yang ada dalam cerita). Setelah post-test dilakukan, kembali dilakukan FGD dengan kelompok mitra untuk membicarakan hasil pembelajaran dan post-test. Hasil FGD dijadikan bahan untuk menyusun laporan akhir kegiatan.

\section{Hasil Kegiatan}

\subsection{Penggunaan dan Pemahaman Bahasa Bali Siswa Kelas IV SDN 8 Dauh Puri}

Indonesia merupakan negara kesatuan yang terdiri dari beribu pulau dengan beragam budaya, bahasa, suku dan agama. Bahasa Indonesia merupakan bahasa pemersatu bangsa, bahasa nasional yang wajib untuk dipakai oleh seluruh warga Indonesia. Dengan banyaknya pulau yang ada, bahasa lokal atau bahasa daerahpun sangatlah banyak jumlanhya. Begitu pula di Bali. Bali, sebagai salah satu pulau bagian kepulauan Indonesia juga mempunyai bahasa lokalnya tersendiri, yaitu bahasa Bali. Namun, seiring dengan perkembangan pariwisata, teknologi, modernisasi, pengarauh IT (social media), penggunaan bahasa Bali sebagai bahasa lokal ataupun bahasa daerah sangat jarang digunakan, utamanya di lingkungan rumah tangga dan sekolah yang ada di perkotaan, salah satu contohnya adalah oleh siswa di SDN 8 Dauh Puri, Denpasar. Sekolah tersebut berada di tengah - tengah kota Denpasar. Siswa - siswi yang bersekolah di SD tersebut kebanyakan pendatang dari berbagai daerah yang ada di Bali dan dari luar Bali. Penggunaan bahasa Bali, selain di hari wajib yang ditentukan oleh pemerintah propinsi Bali untuk menggunakan Bahasa Bali, siswa di sekolah tersebut menggunakan bahasa Bali hanya pada mata pelajaran Bahasa Bali yang diperoleh satu kali dalam seminggu. Hal tersebut sebenarnya telah merangsang mereka menggunakan bahasa Bali, akan tetapi masih perlu dimotivasi lebih intensif untuk membangkitkan minat mereka untuk menguasai dan mneggunakan bahasa Bali.

Saat ini, bahasa Bali sebagai bahasa daerah hanya digunakan oleh kebanyakan orang Bali sebagai alat komunikasi di lingkungan keluarga, khususnya yang hidup di perkotaan. Sehubungan dengan itu, perlu dipikirkan solusi yang berkaitan dengan proses pengajaran dan pembelajaran bahasa Bali di sekolah-sekolah. Proses pengajaran yang diberikan kaitannya dengan pengabdian ini adalah pembelajaran masatua Bahasa Bali. Hal tersebut diberikan agar para siswatermotivasi dan berminat untuk mempelajari dan menggunakanbahasa Bali karena bahasa Bali merupakan bahasa daerah yang harus dipertahankan. Selain itu, pembelajaran mesatua bahasa Bali dipilih untuk diberikan agar para siswa di sekolah tersebut juga mampu memaknai nilai - nilai moral yang terkandung dalam satua Bali tersebut.

Siswa yang ada di kelas IV A dan VI B di sekolah tersebut tidak semuanya memahami bahasa Bali dengan baik. Hal itu dapat dilihat dari kurangnya pemahaman mereka terhadap beberapa kata dan kalimat yang terdapat di dalam beberapa satua Bali yang diceritakan. Sebagai contoh, ada beberapa siswa yang tidak tahu makna beberapa kata, seperti "satua", “endut”, “layah”,"saang”,"jakanka”, "paku”, "geginane”, "jemet”, "pisuna”, "nglesung”, "sengu-sengu”, “mrekak”, "ngemademang”, “tundung”. Ketika 
diberikan cerita, beberapa siswa bertanya apa itu "endut". Pertanyaan tersebut tidak lantas dijawab, namun dilemparkan kembali ke siswa lain. Ketika siswa lain diberikan kesempatan untuk menjawab, dua orang siswa mampu menjawabnya dengan benar. "Endut" adalah lumpur. Salah satu contoh lain adalah ketika siswa mendengar kata "tundung". "Apa itu tundung?" Tanya seorang siswa. Seperti halnya ketika mereka bertanya tentang apa itu "endut", maka kembali pertanyaan dilemparkan dahulu ke siswa lainnya. Setelah menunggu beberapa menit, tidak pula ada yang bisa menjawab apa bahasa Indonesia dari kata "tundung" tersebut. "Tundung" itu artinya usir, kalau ada kata "katundung" kata tersebut mempunyai makna diusir. Dari beberapa pertanyaan tersebut, anak - anak di kelas IV A maupun di kelas IV B dapat dikatakan tidak memahami secara baik kosa kata dalam bahasa Bali. Hal tersebut dipengaruhi oleh bahasa Bali yang tidak digunakan sebagai alat untuk berkomunikasi. Hal ini perlu diperhatikan agar bahasa Bali sebagai salah satu budaya daerah Bali tetap terjaga keberadaannya sehingga masyarakat Bali, terutama generasi muda Bali paham dan mengerti tentang kebudayaan Bali. Hal ini sejalan dengan pandangan Bang dan Door (1993) yang menyebutkan bahwa bahasa tidak bisa dipisahkan dari lingkungannya dan bahasa tidak berarti tanpa lingkungannya. Lingkungan bahasa tersebut berupa lingkungan ideoligis, lingkungan sosiologis, dan lingkungan biologis.

Akan sangat berbeda dengan siswa yang bersekolah di lingkungan pedesaan yang ada di Bali. Penggunaan bahasa Bali pada anak - anak di lingkungan pedesaan masih sangat kental. Hal tersebut dipengaruhi oleh kebiasaan mereka yang masih menggunakan bahasa Bali dalam kehidupan mereka sehari-hari, bahasa Indonesia hanya digunakan di dalam proses belajar mengajar di kelas.

\subsection{Pemahaman siswa kelas IV SDN 8 Dauh Puri Denpasar terhadap nilai - nilai moral yang terdapat pada beberapa Satua Bahasa Bali.}

Pembelajaran Masatua Bali kepada siswa di Kelas IV SDN 8 Dauh Puri Denpasar disepakati untuk diberikan sebanyak enam kali pertemuan. Pada pertemuan pertama, sebelum diberikan satua bahasa Bali, siswa terlebih dahulu dilakukan pre-test (kurang lebih selama 20 menit) terkait dengan nilai-nilai moral dalam kehidupan sehari-hari. Selanjutnya, pada pertemuan-pertemuan berikutnya siswa diberikan beberapa satua Bali yang mempunyai nilainilai moral yang patut mereka pahami kaitannya deng pembentukan dan pengembangan karakter. Pada pertemuan terakhir, setelah dilakukan pembelajaran masatwa berbahasa Bali, dilakukan post test dengan membagikan kuesioner untuk mengukur kemampuan siswa terkait dengan nilai - nilai moral yang terdapat pada satua Bali dan dan hasilnya dibandingkan dengan hasil pre-test.

Seperti yang sudah dipaparkan pada bab sebelumnya, siswa kelas IV SDN 8 Dauh Puri Denpasar, terbagi menjadi dua kelas, kelas IV A terdiri dari 44 orang siswa dan kelas IV B terdiri dari 45 orang siswa. Masing - masing kelas diberikan kuesioner pre- test, satua bahasa Bali, dan kuesioner post- test yang sama.

Hasil pre-test menunjukkan bahwa pemahaman sejumlah siswa terhadap nilai-nilai moral yang terkait dengan kehidupan sehari-hari masih kurang. Dari 44 orang siswa yang ada di kelas IVA, siswa yang mampu memahami makna ataupun nilai moral kehidupan sehari-hari hanya 10 orang siswa, yang kurang memahami ada sebanyak 18 orang, dan yang tidak paham ada sebanyak 16 orang siswa. Begitu pula dengan siswa yang berada di kelas IVB. Dari 45 orang siswa yang menjawab, hanya 15 orang siswa yang mampu menjawab dengan nilai yang baik, 17 orang siswa menjawab dengan nilai yang kurang baik, dan 13 orang siswa tidak paham. Pada proses pembelajaran masatwa bahasa Bali, siswa diberikan beberapa satua Bali, 
seperti yang berjudul (1) I Sugih lan I Tiwas, (2) I Lutung teken I Kekua, (3) I Cupak lan I Grantang, (4) Ni Kesuna lan Ni Bawang, (5) I Cicing Gudig, dan (6) Kambing Takutin Macan. Satua-satua (cerita) tersebut secara garis besarnya menceritakan tentang kehidupan manusia yang menunjukkan sifat baik dan buruk, nilai-nilai yang benar dan salah, tindakan sopan dan kurang sopan, dan sebagainya yang muncul dalam kehidupan sehari-hari, misalnya sifat jujur, baik hati, pelit, iri hati, dengki, pemalas, pemarah, sombong, serakah, dan lainnya.

Secara spesifik dideskripsikan proses pembelajaran sebagai berikut.

Pada pertemuan pertama, siswa diberikan satua Bali yang berjudul "I Sugih lan I Tiwas". Satua tersebut secara garis besarnya menceritakan tentang kisah seorang yang kaya namun sangat pelit dan perhitungan dalam hidupnya, berdampingan hidup dengan seorang yang miskin, namun baik hati dan sangatlah sabar dalam hidupnya walaupun sering dicurangi melakukan hal-hak yang buruk oleh si kaya. Adapun nilai moral yang terkandung di dalamnya adalah jadilah orang yang jujur, baik hati, setia, tidak sombong, dan tidak pelit kepada sesama.

Dalam menyampaikan cerita tersebut, beberapa siswa sempat menyela untuk bertanya tentang beberapa hal yang mereka kurang pahami, mengingat cerita yang disampaikan adalah cerita dalam bahasa Bali. Kata-kata baru yang mereka tidak ketahui seperti contoh "endut" yang artinya adalah "lumpur", disarankan untuk dicatat artinya dalam bahasa Indonesianya, agar siswa dapat mengingat, memahami dan melestarikan bahasa daerah mereka, yaitu bahasa Bali. Beberapa siswa lain sempat menyela untuk bertanya tentang beberapa hal yang mereka kurang pahami, seperti kata degag 'sobong' dan disarankan untuk dicatat artinya dalam bahasa Indonesianya, agar siswa dapat mengingat, memahami dan melestarikan bahasa daerah mereka, yaitu bahasa Bali. Pada pertemuan kedua siswa diberikan cerita yang berjudul "I Lutung teken I Kekua". Cerita tersebut menceritakan tentang seekor kura-kura yang kelaparan dan ingin mencari makan, lalu seekor lutung memberikan petunjuk bahwa si kura-kura dapat mencari makan diseberang sungai di pekarangan rumah seorang kakek yang bernama Ki Prodong. Singkat cerita, si lutung tersebut mengantarkan si kura-kura kesana, namun si lutung yang mencuri dan memakan semua makanan yang dijanjikan oleh si lutung kepada si kurakura. Akhirnya, apa yang dilakukan oleh si lutung diketahui oleh si kakek dan dibunuhlah si Lutung oleh si kakek tersebut. Adapun nilai moral yang diajarkan dari cerita tersebut adalah tidak boleh berbohong apalagi sampai mencuri.

Sama halnya dengan pertemuan sebelumnya, ketika mereka diberikan satua Bali, beberapa siswa ada yang menyela dan menanyakan tentang kata-kata baru yang mereka dapatkan. Sama seperti pertemuan sebelumnya, mereka diberikan penjelasan tentang kata baru tersebut dan mereka pun mencatat kembali arti dari kata tersebut.

Pada pertemuan ketiga siswa diberikan satua Bali yang berjudul "Cupak Grantang”. Cerita tersebut secara umum menceritakan tentang kisah dua orang bersaudara yang mempunyai karakter yang sangat berbeda. Si kakak yang bernama Cupak mempunyai perawakan yang besar, dengan wajah yang bringasan dengan sifatnya yang suka berbohong, rakus dan senang mengadu domba, sedangkan si adik yang bernama Grantang mempunyai perawakan tinggi dengan wajah yang rupawan dengan sifatnya yang polos dan baik hati. Secara umum cerita tersebut menceritakan tentang kemarukan si Cupak terhadap adiknya sendiri. Cerita ini memberikan pesan moral agar jangan berbuat jahat terhadap saudara sendiri maupun orang lain. Seperti pertemuan sebelumnya, siswa masih ada yang suka bertanya tentang kata dalam bahasa Bali yang mereka tidak pahami. Ketika mereka diberikan satua Bali, beberapa siswa ada yang bertanya tentang kata-kata baru yang mereka dapatkan. Sama seperti pertemuan sebelumnya, mereka diberikan penjelasan tentang kata baru tersebut dan mereka pun mencatat kembali arti dari kata tersebut. Banyak pesan moral yang disampaikan dalam cerita tersebut, diantaranya: kita wajib bersyukur tentang apa yang telah diberikan oleh Tuhan, kita tidak 
boleh loba, dan sebagainya. Pertemuan keempat, siswa di kelas tersebut diberikan satua Bali tentang "Ni Kesuna lan Ni Bawang". Sama halnya dengan satua Cupak Grantang, secara umum cerita tersebut menceritakan tentang kisah dua bersaudara yang mempunyai rupa, sifat, dan karakter yang sangat berbeda. Si bawang yang cantik, polos dan baik hati dan si Kesuna yang selalu mempunyai sifat iri hati. Cerita tersebut memberikan pesan moral yang kurang lebih sama dengan cerita Cupak Grantang .

Pada pertemuan kelima, satua yang disampaikan kepada siswa berjudul I Cicing Gudig. Dalam satua tersebut dikisahkan tentang anjing yang bernama I Cicing Gudig yang tidak pernah bersyukur akan dirinya. Pertama dia berdoa agar doanya dikabulkan dan ia bisa berubah menjadi manusia. Selanjutnya, ia kembali berdoa agar dia bisa menjadi patih. Setelah doanya dikabulkan, dia kembali tidak puas akan dirinya. Kemudian dia berdoa lagi mohon menjadi seorang raja. Setelah dia menjadi raja, dia bahkan tidak bisa menjalankan tugasnya sebagai raja. Akhirnya, dia berdoa lagi memohon agar dia bisa dikembalikan menjadi seekor anjing. Sama seperti pertemuan sebelumnya, mereka diberikan penjelasan tentang kata baru tersebut dan mereka pun mencatat kembali arti dari kata tersebut. Banyak pesan moral yang disampaikan dalam cerita tersebut, diantaranya: kita wajib bersyukur tentang apa yang telah diberikan oleh Tuhan, kita tidak boleh loba, dan sebagainya.

Pada pertemuan keenam, sebagai pertemuan terakhir, satua (cerita) yang disampaikan kepada siswa berjudul "Kambing Takutin Macan". Dalam cerita tersebut diceritakan tentang Si Kambing yang memiliki tubuh yang lemah tetapi memiliki kecerdasan yang tinggi sehingga dia mempunyai banyak akal. Sebaliknya, si macan memilki tubuh yang sangat kuat dan buas, tetapi memilki kecerdasan yang rendah. Dengan demikian, si Macan dengan mudah dibodohi oleh si Kambing. Pesan moral yang ingin disampiakan dalm cerita tersebut adalah kita tidak boleh merendahkan orang lain dilihat dari tubuh/fisiknya. Sebaliknya kita tidak boleh sombong dengan tubuh yang kuat tetapi memiliki kecerdasan yang rendah.

Selanjutnya, pada pertemuan terakhir ini, kuesioner untuk post-test diberikan kembali kepada para siswa untuk memastikan apakah ada peningkatan pemahaman terhadap nilai-nilai moral setelah diberikan beberapa satua bahasa Bali dalam 6 minggu. Dari hasil post-test, terlihat bahwa ada peningkatan tentang pemahaman siswa terhadap nilai-nilai moral yang terdapat di dalam beberapa satua bahasa Bali yang diberikan yang terkait dengan kehidupan sehari-hari. Kelas IV A dengan jumlah siswa 44 orang siswa mampu menjawab dengan benar semua pertanyaan yang ada di dalam kuesioner tersebut sebanyak 40 orang. Dengan demikian ada peningkatan dalam proses penyampaian satua bahasa Bali tersebut sebanyak. Pada pre-test siswa yang mampu menjawab dengan benar hanya 10 orang, namun setelah diberikan satua bahasa Bali, yang mampu menjawab kuesioner tersebut adalah 40 orang. Demikian pula dengan kelas IVB. Pada pre-test siswa yang mampu menjawab benar semua hanya 15 orang, namun setelah diberikan satua bahasa Bali, siswa yang mampu menjawab sebanyak 42 orang siswa. Hal ini menunjukkan bahwa satua bahasa Bali mampu memberikan pengaruh yang baik dalam membentuk karakter generasi muda Bali. Melalui pengajaran masatwa bahasa Bali dan menggunakan bahasa Bali sebagai media pendekatan komunikasi ternyata mampu meningkatkan pemahaman siswa terhadap nilai-nilai moral kehidupan seghari-hari yang terkait dengan pembanguan/pembentukan karakter, khususnya siswa kelas IV di SDN 8 Dauh Puri Denpasar. Dengan memberikan cerita yang mengandung nilai - nilai moral kepada siswa kelas IV SD, diharapkan agar siswa mampu menyimak, memaknai dan menerapkan nilai-nilai moral yang terkandung dalam beberapa satua Bali yang telah diberikan. Seperti yang sudah disampaikan, siswa SD dijadikan target, karena anak di usia tersebutlah yang paling mudah untuk dibentuk karakternya. Selain itu, dengan memberikan pengajaran masatua Bahasa Bali tersebut diharapkan agar generasi muda sebagi generasi penerus Bali mampu menjaga dan 
melestarikan bahasa Bali dan nilai-nilai moral yang melekat dalm kehidupan berbudaya di Bali.

\section{Kesimpulan}

Pembelajaran Masatua Bahasa Bali diberikan kepada Siswa Kelas IV SDN 8 Dauh Puri Denpasar dengan tujuan untuk meningkatkan kecintaan dan kemampuan siswa terhadap bahasa Bali sebagai bahasa daerah masyarakat Bali yang biasa digunakan dalam hubungannya dengan agama, adat, dan istiadat. Disamping itu, tujuan lain dari masatwa bahasa Bali tersebut adalah untuk memperkuat moral generasi muda Bali dalam membangun karakter bangsa, khususnya generasi muda Bali melalui pesan-pesan moral yang terkandung dalam satua tersebut. Setelah dilakukan pengabdian selama 6 minggu, hasilnya menunjukkan bahwa pendekatan melalui pengajaran masatwa bahasa Bali kepada anak-anak siswa kelas IV di SDN 8 Dauh Puri Denpasar mampu meningkatkan pemahaman siswa terhadap nilai-nilai moral kehidupan sehari-hari dalam kaitannya untuk membangun karakter generasi muda Bali. Di samping itu, melalui masatwa bahasa Bali, siswa juga dapat menigkatkan kemampuan dan kecintaannya dalam memahami dan menggunakan bahasa Bali sehingga bahasa Bali tetap lestari sebagai salah satu kebanggaan masyarakat Bali yang digunakan untuk menyampaikan kebudayaan Bali.

\section{References}

[1] Azhari, Akyas. 2004. Psikologi Umum dan Perkembangan. Jakarta Selatan: Teraju.

[2] Bang, Jørgen Chr. dan Jørgen Døør 1993. Eco-Linguistics: A Framework. Situs: (www.jcbang.dk/main/ecolinguistics/Ecoling_AFramework1993.pdf) diakses pada tanggal 22 September 2015.

[3] Cahyo, Agus N. 2013. Panduan Aplikasi Teori-Teori Belajar Mengajar. Yogyakarta: Diva Press.

[4] Dali, Gulo. 1987. Kamus Psikologi. Bandung: Pinoir Jaya

[5] Ismoerdijahwati, K. 2007. Metode Bercerita. Surakarta: FKIP UNS.

[6] Mbete, Aron Meko. 2014. "Manfaat Kajian Ekolinguistik dalam Upaya Pelstarian Bahasa, Budaya, dan Lingkungan". Dalam Prosiding Seminar Nasional Ekolinguistik, Medan: Lembaga Kajian Ekolinguistik. (LKE)

[7] Searle, John R. 1990. Speech Acts. Berkeley: University of California

[8] Suarjana, Putra I Nyoman. 2011. Sor Singgih Bahasa Bali (ke-bali-an Manusia Bali Dalam Dharma Peparikan, Pidarta, Sambrama Wecana dan Dharma Wecana). Denpasar: PT. Tohpati Grafika Utama

[9] Subyantoro, 2013 Pembelajaran Bercerita : Modal bercerita untuk meningkatkan kepekaan emosi dalam berapresiasi sastra, Yogyakarta: Penerbit Ombak 